\title{
Представление о крепком сне в славянских языках (на материале устойчивых сравнений)*
}

\begin{abstract}
Е. К. НИКОЛАЕВА, Е. И. СЕЛИВЕРСТОВА
Кафедра русского языка и предвузовской подготовки, Российский государственный гидрометеорологический университет, Малоохтинский пр., д. 98, RU-195196 Санкт-Петербург

Кафедра русского языка для гуманитарных и естественных факультетов, Санкт-Петербургский государственный университет, Университетская наб., д. 11, RU-199034 Санкт-Петербург

E-mail: elena_kairovna@mail.ru, selena754@inbox.ru
\end{abstract}

(Received: 28 May 2016; accepted: 5 August 2016)

\begin{abstract}
This paper deals with the comparative analysis of Slavic similes that characterize sound sleep as a part of the linguistic image of the Slavic world. Through the analysis of the figurative structure of similes, the authors demonstrate a great variety of models describing sound sleep in Slavic similes as well as the distinctive and similar ways of expressing the main meanings of similes in different languages. They also demonstrate the semantic differentiation of similes created by the model used in the comparison. Finally, the authors describe several national or cultural specific features of similes in various Slavic languages.
\end{abstract}

Keywords: Slavic languages, comparative analysis, similes, linguistic image, semantics

Устойчивые сравнения (УС) составляют крупный и важный структурносемантический разряд фразеологических единиц (ФЕ), отмеченных яркой лингвокультурологической специфичностью. В них непосредственно отражаются особенности образного мышления носителей разных языков, и потому их отличает неповторимая самобытность.

Тонкий и точный выбор образов сравнений определяет их особую экспрессивность, основанную, прежде всего, на том, что основой для УС становятся наблюдения из наиболее актуальных и традиционных сфер жизни и деятельности человека. Чтобы поражать воображение, образ, проецируемый по принципу аналогии на разные предметы и явления окружающего мира, должен быть общепонятным и ярким. Вот почему ядро многих сравнений составляют образы животного и растительного мира, традиционного крестьянского быта, производственной деятельности человека или духовной сферы жизни - например, мифологии, религии и т. д. Так, только со словом собака в русской народной речи - с учетом данных диалектного и фольклорного материала - можно насчитать свыше 300 устойчивых сравнений (МоKIENKOWALTER-VALODZINA 2004: 192).

* Работа выполнена при финансовой поддержке Российского гуманитарного научного фонда. Проект «Ключевые концепты русских народных сравнений (опыт идеографического словаря)» (№ 14-04-00090/14; шифр ИАС 31.16.571.2014). 
Сравнительно-сопоставительный подход, используемый при анализе материала как родственных, так и генетически далеких языков, позволяет видеть, в чем состоит различие и сходство в способах выражения отдельных смыслов, определить, «как в разных языках удовлетворяются сходные функциональные потребности, глубже вскрыть функциональную эквивалентность языков на различных языковых уровнях при сопоставлении как системном, так и функциональном» (ШироковА 1988: 10).

При всем разнообразии подходов к изучению устойчивых сравнений (идеографического, лингвокультурологического, структурно-семантического, когнитивного, переводческого и проч.) нельзя не отметить важности сравнительно-сопоставительного подхода к описанию и анализу компаративных выражений в разных языках, если они рассматриваются с точки зрения познания «духа языка», с позиций типологии культуры и национального менталитета, позволяющих показать особенности мировидения и миропонимания носителей языка. Как писала В. Н. Телия, эталонные сравнения «являются результатом собственно человеческого соизмерения с „нечеловеческими“ свойствами, носители которых воспринимаются как эталоны свойств человека» (ТЕлия 1996: 241-242). Эти особенности могут проявляться в выборе тех фрагментов действительности, которые представляются особенно важными для носителей разных языков и культур и, таким образом, получают многократные и самые разнообразные отражения в языке в виде устойчивых сравнений.

С другой стороны, ментальные особенности представителей того или иного этноса проявляются и во «внутрифразеологической избирательности», состоящей в вовлечении в процесс образования УС определенных языковых единиц, которые становятся эталонами сравнения. Именно в них проявляется специфика образного видения мира, поскольку отбор этих образов осуществляется на протяжении веков, закрепляется в языке и передается из поколения в поколение, раскрывает многие стороны исторического развития народа, особенности его быта и культуры, его дух и образ мыслей - иначе говоря, культурная значимость образности устойчивых сравнений определяется системой образов-эталонов, положенных в основу сравнения, их предпочтительным выбором, характером даваемой ими оценки и частотностью использования в качестве семантической основы УС. Именно образ фразеологизма, по мнению М. Л. Ковшовой, служит «проводником» в культурное пространство - актуализирует знания о происхождении ФЕ, о связанных с ней ритуалах, обрядах, поверьях, мифах и т. д.; именно образ «будит» в сознании окультуренные представления, вызывает ассоциации с различными предметами, текстами, действами, устанавливает связь с воплощенными в них культурными смыслами и, обогащенный культурной семантикой, «возвращается» во фразеологизм (КовшовА 2013: 175). Образ каждой УС, как правило, неповторим, что рождает особую семантическую дифференцированность устойчивого сравнения, ту самую «добавочность смысла», о которой писал Б. А. Ларин и которая хорошо видна при анализе составляющих синонимиче- 
ские ряды УС, что будет показано ниже на примере сравнений с общим значением «спать».

К настоящему времени накоплен значительный опыт наблюдения за особенностями отражения окружающего нас мира в компаративных фразеологических единицах (см., например, АлЕшин 2012, Бойко 2009, ВоРОБьЕВА 2002, ЖУМАНБЕКОВА 2013, ЛЕБЕДЕВА 1999, КУЗНЕЦОВА 2011, КУЗНЕЦОВА 2012, КЮвЛИЕВА-МишАЙКОВА 1986, МАЛЬКОВА 2015, МизИН 2011, НиКОЛАЕВА 1989 , НиколАева 2015, Полищук 2014, FinK 2010, MENAC-Minalić 2003-2004, WySOCZAŃSKI 2005 и др.). Славянские языки располагают серьезными фразеологическими источниками, систематизирующими устойчивые сравнения и создающими основательную базу для лингвокультурологических исследований (см., например, SP, SČFI, CCHП, СБНП, FINK 2006, ЛЕВчЕНКо 2012, ОГОЛЬЦЕВ 2001, Мокиенко 2003 и др.). Самым значительным источником компаративных фразеологизмов русского языка, на который мы опираемся в данной работе, является вышедший в 2008 году «Большой словарь русских народных сравнений» (БСРНС), вобравший в себя более 45 тысяч образных выражений, почерпнутых из классической и современной литературы XVIII-XXI вв., публицистики и средств массовой информации и сопровождаемых объяснением значения и, что весьма важно, экспрессивно-стилистическими и региональными пометами.

В массиве компаративных единиц обращают на себя внимание тщательная проработка, детализация образными средствами с разных точек зрения самых важных для человека действий - таких, например, которые можно обобщить словами жить, работать, смотреть, есть, бежать, врать, говоpumb, cuдеть и проч. При этом для говорящих оказываются актуальными характер и условия протекания того или иного действия, его интенсивность, скорость и способ его осуществления; ср. современные русские УС врет, что черт; врет, как свидетель и приведенные еще В. И. Далем УС врет как газета (Даль 1: 259); врет, как по-печатному (по-писаному, по-газетному); врать, как сивый мерин; врет, как редьку стружит (садит); врет, что помелом метет; врет, что блины печет : только иипит; врет, как водой (в уброд) бредет (Даль 1974: 157-158).

Избранный нами для анализа фрагмент языковой картины мира, репрезентируемой устойчивыми сравнениями славянских языков, построенными по модели спит как кто / что и характеризующими «качество сна», интересен уже тем, что он, с одной стороны, представлен в самых разных языках мы находим подобные выражения в китайском (спать как [мертвая] свинка 'спать крепко, сладко, долго', 'храпеть'; спать как младенец 'спать сладко, красиво...'), шведском (sova som en klubbad säl 'спать как забитый тюлень'; sova som en sten 'спать как камень'; sova som en stock 'спать как бревно'; somna/sova som en klubbad oxe 'засыпать/спать как забитый вол'; sova som ett gott barn 'спать как хороший ребенок'), индонезийском (tidur seperti kerbau ['спать как буйвол'] - 'спать крепко, долго'). Поэтому и в языковой картине мира любого славянского этноса эта группа достаточно весома (см., 
например, работы хорватской исследовательницы Жельки Финк-Арсовски: FINK 2007, FINK 2012).

С другой стороны, объединенные общим значением устойчивые единицы демонстрируют большое разнообразие нюансов - как в части оттенков значения, так и в характере используемых образов. Этот фрагмент действительности представлен в языке очень широко, поскольку сон в жизни человека является важной и безусловной потребностью. Во сне среднестатистический человек проводит треть своей жизни, т. е. около 25 лет. Кроме того, в мифологическом сознании славян сон - это «состояние человека, уподобляемое смерти (,вечному сну“), и один из каналов связи с потусторонним миром» (СД 5: 119), что нашло явное отражение в сравнении сна со смертью: спать как убитыли; пск. спать (лечь, заснуть) как помёрши (помёрли) (БСРНС 522); грубо-прост. спать как сдох (БСРНС 605); пск. спать как умер (умёрии) (БСРНС 707).

Изучение семантики компаративных фразеологизмов группы «Спать» показывает, что важными критериями оценки качества сна являются развиваемые в УС адвербиальные значения ‘крепко' и ‘чутко', состоящие в отношениях антонимии и позволяющие выделить, соответственно, две группы единиц, внутри которых сравнения объединены дополнительными семантическими оттенками. Предметом анализа в данной статье является группа УС со значением 'спать глубоко, крепко', которая значительно превышает группу ‘спать чутко’ количественно и отличается бо́льшим разнообразием образов.

В группе с семантикой 'спать крепко' возможно выделение нескольких подгрупп - в зависимости от того, какой дополнительный оттенок отмечается в семантике сравнительного оборота. Приведем их последовательно.

\section{1. 'Спать крепко, безмятежно, спокойно'}

В УС славянских языков, содержащих семантический оттенок 'безмятежно, спокойно', обнаруживается полное совпадение некоторых образных стержней. Универсальным является образ спящего ребенка, включающий представление о новорожденном, грудничке (т. е. вскармливаемом грудью), ${ }^{1}$ младенце, еще не умеющем говорить: рус. спать (заснуть) как [невиннылй] младенец (как ребенок) (БСРНС 396); спать (заснуть) как новорожденньий (БСРНС 440); болг. спя (заспивам /заспя) като бебе; спя като детенце (младенеи) (БРФ 334); пол. spać jak [nowo narodzone] dziecko (NKPP 3: 278); spać jak nowo narodzony (SP 160); zasnqć (spać) jak niemowlę (NKPP 3: 278); spać jak noworodek (SP 160); слвн. zaspati (spati) kot dojenček (otrok) ['ребенок'] 'спокойно, беззаботно' (FINK 2012: 57); слвц. zaspat' (spat') ako nemluvn̆a (koje-

\footnotetext{
1 Этот образный стержень представлен не только в славянских языках, но является общеевропейским, что показано в статье Ж. Финк, где приводятся УС 16 языков - помимо славянских, исп. dormir como un bebé (un bendito), итал. dormire come un neonato (un bambino, un bimbo, un bebé), англ. sleep like a baby, франц. dormir comme un nouveau-né (un bébé), нидерл. slapen als een baby, швед. sova som en bebis и др. (FINK 2012).
} 
nec) (FINK 2012: 57); хорв. zaspati (spavati) kao beba (FINK 2007: 283); макед. заспие (спие) ко бебе (бајче) (FINK 2012: 57); серб. спава као новорођенче; чеш. usnout (spát) jako dítě (nemluvně) (SČFI 224). Широко представлено сравнение с ангелом - символом чистоты, кротости и непорочности ('спит как ангел'): пол. śpi jak anioł (SFJP 87); болг. спя като ангелче; чеш. spát jako anděl [andělíček, andílek] (SČFI 34); хорв. spava kao anđeo (BC 2004: 23) и др.

Семантика этих оборотов, с одной стороны, вытекает из сравнения спящего человека с ребенком, который обычно спит больше, а нередко и крепче взрослого, а с другой стороны, образ спящего ребенка, как и образ ангела, порождает ассоциации с безгрешностью, невинностью и отсюда - с чистой совестью, которая и позволяет безмятежно спать. ${ }^{2}$

Экспрессивность оборотов повышается в отдельных УС за счет введения в их состав компонентов, детализирующих образную основу - как это происходит в сравнениях болг. заспя (заспивам/спя) като [къпано] дете (КЮвЛИЕВА-МишАЙКОВА 1986: 199), пол. śpi jak niemowle po kapieli (NKPP 3: 278), расширенных за счет лексем къnано 'выкупанный' и po kapieli 'после купания', и в ряде оборотов с определением маленький (ребенок, младенец): болг. заспя (спя) като [малко] бебе (FINK 2012: 57); слвц. zaspat' (spat') ako [malé] diet'a (FINK 2012: 57); пол. spać jak [mate] dziecko (FINK 2012: 57). Усилительное значение привносят и определения грудной, невинный: рус. сnать, заснуть как грудной (невиннылй) младенеч 'о безмятежном, спокойном, сладком и глубоком сне' (БСРНС 396).

Использование в качестве объекта сравнения образа рыбы или птицы характерно только для чешского языка. Интересно, что название рыбы - речь идет о гольце (о рыбе семейства лососевых) - использовано в УС spí jako mřené ‘будучи усталым, спать крепко, беспробудно' (SČFI 215) в форме, характерной для оформления наименований молодых существ (сp. kotě, štěně), что в известной степени приближает данный оборот к выражению spí jako dítě. Однако это не проясняет до конца его внутренней формы. Возможно, объяснение кроется в следующем: речной голец скрывается в зимнее время в глубокий омут и выходит из него только весной (ср. с зимней спячкой медведя в берлоге).

С синхронной точки зрения внутренняя форма чешского сравнения spí jako dudek ['удод'] также представляется не совсем ясной: словарь чешских сравнений проясняет ее, на наш взгляд, не совсем убедительно: «У удода в гнезде очень грязно и сильный запах. Сравнение первоначально относилось к маленьким детям, спящим так крепко, что им не мешали испачканные

\footnotetext{
${ }^{2}$ В комментариях к произведениям живописного искусства - часто к картинам религиозного содержания - указывается на порождаемую образом спящего ребенка коннотацию 'невинность', 'безгрешность'. Ср.: «Строгий реализм и глубина передачи чувств характеризуют творчество Микеланджело Меризи, известного под именем Караваджо. Это подтверждает его полотно „Спящий амур“, где светлый образ спящего ребенка прекрасно гармонирует с идеей художника, который благодаря игре света выявляет истинный сюжет картины: невинный детский сон» (Флоренция 2008: 148).
} 
пеленки» (SČFI 92). Высказанная версия вызывает сомнение в силу того, что dudek - это взрослая особь, а не птенец удода, так что, вероятно, способность спать в таком гнезде - свидетельство крепкого сна не только у птенцов. ${ }^{3}$

Особым мотивом объединены обороты с образом спящего праведника человека, живущего правильной жизнью, не погрешающего против правил нравственности, морали - он безгрешен, как и ребенок/ангел. При этом мы находим обороты со сравнительным союзом: болг. спя като праведник (БРФ 455); рус. спать/уснуть/заснуть как праведник (БСРНС 532), а также с иной, весьма распространенной структурой: спать сном праведника (БСРНС 532); серб. спавати сном праведника (FINK 2007: 281); хорв. spavati snom pravednika (FINK 2007: 281); пол. spać snem sprawiedliwego ['mocno, spokojnie, nie mając nic na sumieniu'] (SFJP 164).

\section{2. 'Спать крепко, безмятежно, в удобном положении'}

Данное значение представлено незначительным количеством УС: рус. книжн.-поэт. спать (уснуть) как цүарица; спать (уснуть) как изарь 'о чьемлибо крепком, блаженном, безмятежном сне' (БСРНС 729), спит как барон (БСРНС 36); пол. śpi jak król; śpi jak król portugalski (NKPP 3: 278). Компонент portugalski употребляется здесь как интенсификатор, не несущий семантической нагрузки, связанной с буквальным значением лексемы, т. е. для повышения экспрессивности высказывания. Общим для всех УС этой группы является сравнение с людьми, принадлежащими к высшим социальным классам, жизнь которых протекала в роскоши и безмятежности - по мнению простого народа, чьими устами формулируются яркие образные единицы. Сюда же можно отнести и УС рус. шутл. спать как молодой бог 'о крепко спящем молодом и красивом человеке' (БСРНС 55), хотя в семантике данного УС превалирует характеристика внешности спящего молодого мужчины.

Представление о крепком, безмятежном сне в удобном месте нашло отражение в рус. спать (покоиться) как в кольлбели (БСРНС 279); спать где как в люльке (БСРНС 365) и польских УС: śpi jak v puchu; śpi jak ser w pierogu 'удобно, уютно устроившись' (NKPP 3: 278). Словацкие УС развивают мотив спокойного, сладкого сна в жидкой субстанции - молоке, растительном масле: spat’ ako v oleji (ako v mlieku) (SMIEŠKOVÁ 1974: 173).

\section{3. 'Спать много, долго'}

Сравнительные обороты группы, характеризуя «качественный» сон, развивают дополнительный семантический нюанс 'много, долго', при этом контекстуальные оценки такого сна варьируются от позитивной до негативной.

\footnotetext{
${ }^{3}$ Известно, что с помощью жидкости, имеющей резкий неприятный запах, удоды пытаются защититься от некрупных наземных хищников в период насиживания и кормления птенцов. По этой причине в глазах человека птица приобрела репутацию очень «нечистоплотного» существа.
} 
Многие УС рассматриваемой группы основаны на сравнении сна человека и животного. Характерно, что объектом сравнения в большинстве случаев являются животные, существенную часть года - зиму, а иногда и часть осени и весны - проводящие в спячке или зимнем оцепенении. В первую очередь, это широкий круг представителей семейства грызунов: рус. сnать / уснуть как сурок (суслик) (БСРНС 668); спать как байбак [в норе] 'о сонливом, постоянно спящем человеке' (БСРНС 29); спать как хомяк (БСРНС 725); болг. заспя (спя) като пор ['хорек'] (БРФ 448); спя като крът ['крот'] (НБФР 2: 289); пол. śpi jak suset (bobak, świstak) ['суслик', 'байбак, сурок'] (NKPP 3: 277); слвц. zaspat' (spat') ako sysel' ['суслик'] (SM 229); чеш. spát jako sysel (SČFI 343) и зафиксированные исследователем Ж. Финк слвн. spati kot polh ['соня']; укр. заснути (спати) як бабак ['байбак, сурок']; хорв. zaspati (spavati) kao hrčak (puh) ['хомяк', 'соня, полчок'] (FINK 2007: 283).

Впадающий на зиму в спячку крупный представитель семейства куньих (барсук) также присутствует в УС; о нем известно также, что это осторожное животное выходит из своей норы только по ночам, а днем преимущественно спит. Ср.: рус. спать (отсыпаться) как (ровно) барсук - 'крепко и долго' (БСРНС 37); пол. śpi jak borsuk (NKPP 3: 277); слвн. spati kot jazbec; укр. заснути (спати) як борсук у норі (ССНП 18).

Образом медведя, известного своей продолжительной зимней спячкой, объединены УС многих славянских языков: слвц. spat'ako medved'; хорв. spavati kao medvjed (FINK 2012: 49); пол. drzemie jak niedzwiedź w zimie (WYsoCZAŃSKI 2005: 128); рус. спать (заспаться, дрыхнуть) как медведь [в берлоге] 'спать крепко, беспробудно и долго' (БСРНС 384); залечь как медведь в берлогу [на зимовку, на зимовочку] 'о крепко и надолго улегшемся спать человеке' (БСРНС 383). «Большой словарь русских народных сравнений» фиксирует и диалектное УС: новг. спать как мерлог ['медведь'], реализующее значение 'спать подолгу, томясь от безделья' (БСРНС 388).

Для польского УC spać jak najęty (WySOCZAŃSKi 2005: 269) характерно развитие коннотаций 'усердно, ревностно, интенсивно - даже слишком' и восприятия действия, характеризуемого этим выражением, как предосудительного. В польском языке с приведенной сравнительной частью могут сочетаться самые разные глаголы: gadać jak najęty, krzyczeć jak najęty, klamać jak najęty, latać jak najęty, śmieje się jak najęty и др. (WYSOCZAŃSKI 2005: 269). Это свидетельствует о десемантизации правой части сравнения УС. ${ }^{4}$

\footnotetext{
4 Этот сравнительный компонент активен и в УС чешской разговорной речи, хотя он и не фиксируется словарями; ср. dělat něco jako najatý - jist, lhát, živit se и т. д.; «Čas pádí jako najatý» (www.fler.cz); «S mnohem větším zapálením než kdykoli předtím začal dřit jako najatý» (www.nutrisport-magazin.cz); «Šaman u LUCIE se rozplýval chválou, jedl jako najatej, všechno zbodnul» (diskuze.maminkam.cz); «Zatím jsem našel jen dráty co vedou k tomu repráku co řve jako najatej» (www.chipforum.cz); «Pokud člověk funguje jako ,,automat na kávu“ či jako najatý, byt' velmi profesionální, žoldák?» (http://btci.cz/obchod/jak-motivovat-obchodniky-1-dil); «Ano, ten trpaslík, pravděpodobně proto, že si z loňska příchod Mikuláše nepamatoval, řádil jako najatej» (www. iprima.cz/discussion/121961?page=3) и т. д.
} 
К этому же ряду относятся чешские сравнения, отличающиеся своей образностью от остальных славянских единиц: spát jako do foroty 'про запас, впрок'; spát jako do dichodu 'как будто [копит] на пенсию/как на пенсии' (SČFI 102). Сравнительный компонент первого из них заимствован из немецкого языка «der Vorrat - zásoba, rezerva, dispozice» (http://slovnik-cizich-slov. abz.cz/web.php/slovo/forota).

УС чешского языка spát jako Šipková Růženka содержит сравнение с героиней сказки братьев Гримм «Шиповничек», которая, уколов себе шиповником палец (в сказке Ш. Перро «Спящая красавица» фигурирует веретено), надолго заснула. В комментарии к этому обороту подчеркивается, что единица способна развивать контекстуальный оттенок значения 'в контрасте с теми, кто работает' (SČFI 306). В русском и польском языках эта сказка Ш. Перро отразилась в метафорических фразеологизмах: рус. спящая красавиц̨а; пол. śpiaca królewna (NKPP 2: 214), однако значение этих единиц иное: 'об апатичной, медлительной девушке'.

\section{4. 'Спать беспробудно, крепко'}

Это самый значительный блок единиц в группе УС, характеризующих крепкий сон.

Представление о крепком сне формируется в подобных единицах часто за счет сравнения с чем-то неподвижным, тяжелым. Спать крепко, без малейшего движения, без реакции на проявления внешнего мира - такая ассоциация фиксируется сравнением спящего с мертвым, убитым, характерным для всех славянских языков, ср.: рус. спать (заснуть) как убитый (БСРНС 699), спать как неживой (мертвый); укр. спить як мертвий (ССНП 91); спить мов забитий (ССНП 56); бел. спацьь як забіты (СБНП 158), болг. спя (заспивам/заспя) като мъртъв (покойник) (БРФ 343, 577), спя (заспивам) като пребит (БРФ 343, 577); пол. śpi jak martvy; śpi jak zabity (NKPP 3: 278); серб. сnя като убит (пребит); заспати као мртав (РСХКЈ 2: 221); хорв. spavati (zaspati) kao mrtav (MATEŠIĆ 1979: 251); чеш. spát jako zabitý (ČRFS 486); слвц. spat' ako zabitý (SMIEŠKOVÁ 1974: 229).

При этом, как видим, в некоторых оборотах конкретизируется и способ лишения человека жизни: рус. спать (дрыхнуть/храпеть) как зарезаннылй (БСРНС 211) полностью соответствуют болг. спя като заклан (БРФ 214); бел. cnаџь бы зарэзаны (СБНП 160); пол. śpi jak zarżnięty (NKPP 3: 278); серб. cnaва као заклан; слвц. spat' ako zarezaný (zabitý, zaklaný) (SMIEŠKOVÁ 1974: 229); хорв. spavati (zaspati) kao zaklan и чеш. spát jako zařezaný (ZAORÁLEK 2009: 723). Но особенным разнообразием «уточнений» отличается болгарская парадигма УС: помимо разнообразия способов ухода из жизни (спя като разпран ['распоротый']; спя като удавник ['удавленник']), здесь отмечено и необычное сравнение, в котором проявилась экстралингвистическая информация - вероятно, события болгарско-турецких конфликтов: спя като заклан (резан) турчин [“как зарезанный турок’] (КювлиЕВА-МишАйковА 1986: 199). 
В польском языке в конце XIX в. также фиксируется оборот śpi jako zarżnięty Turek (NKPP 3: 279), где компонент турок детализирует образную основу УС как зарезанный, усиливая экспрессивность выражения.

В чешском и словацком языках для характеристики особенно крепкого сна использован мотив водной стихии, ср.: слвц. spi jakoby ho do vody hodil (SMIEŠKovÁ 1974: 230); чеш. spát jako by ho utopil; spát jako když do vody padne (ZAORÁLEK 2009: 723). Фразеографы при этом отмечают особенность ситуации употребления подобных УС: «столь крепким сном спит человек, очень уставший или больной» (ČRFS 383), т. е. как будто «выпавший» из привычной жизни. На наш взгляд, это «выпадение» из общего хода жизни представлено и в бел. спаць як за сияну заваліўся 'спать крепко' (МРБС 25).

Недвижимость крепко спящего человека порождает многочисленные ассоциации с различными предметами, наблюдаемыми и используемыми в трудовой, хозяйственной деятельности человека. В создании семантики 'крепко, неподвижно' чрезвычайно активными являются в УС самые разнообразные деревянные предметы, независимо от их хозяйственного назначения, но в первую очередь отличающиеся значительным весом и размером как, например, представленная во многих языках колода: пол. spać jak kłoda (SP 161); рус. спать (дрыхнуть, уснуть) как колода (БСРНС 276); серб. спавати (заспати) као клада (РСXКЈ 2: 221); слвц. spat'ako klát (FINK 2006: 107); слвн. zaspati (spati) kot klada (FINK 2006: 107); укр. заснути (сnати) як колода (FINK 2006: 107); хорв. zaspati (spavati) kao klada (FinK 2007: 284); чеш. spát jako kláda ${ }^{5}$ и др. В отдельных языках мы находим образы других крупных частей дерева, в том числе обработанных: это бревно - рус. спать как бревно; болг. спавати (заспивам/заспя) като пън [“бревно, чурбан, пень'] (БРФ 480); пень - болг. спавати като кютюк; пол. śpi jak pień (SP 160); чеш. spát jako pařez (ČRFS 136); древесина, дерево - 'материал', 'какой-либо фрагмент дерева': болг. спавати као дрво ['дерево, полено']; пол. śpi jak drewno ['кусок дерева, полено'] (SP 160); серб. спавати као дрво; слвц. zaspat' (spat') ako drevo (SMIEŠKovÁ 1974: 229); чеш. usnout (spát) jako dřevo (ČRFS 376).

Очень близки в этом смысле восточно- и западнославянские языки, в которых представлен широкий «ассортимент» наименований частей дерева, древесины; ср.: пол. śpi jak drewno ['кусок дерева, полено'] (SP 160); рус. спать как чурка (чурочка) (БСРНС 752); спать как чурбан (БСРНС 751); диал. спать как бич ['короткая деревянная палка'] (БСРНС 50); диал. спать как колчужка ['колода, обрубок, дерево'] (БСРНС 279); диал. спать как лыко (БСРНС 363); слвц. zaspat' (spat') ako kus dreva (poleno); укр. заснути (сnати) як поліно; заснути (спати) як дровиняка ['дрын, деревяха'] (FINK 2006: 173);

${ }_{5}^{5}$ Выражение, не зафиксированное чешскими лексикографами, но встречающееся в устной разговорной речи: «Hrozně rád se mazlí, prakticky jde spát rovnou s námi a spí jako kláda do 5ti hodin do rána» (https://www.facebook.com/permalink.php?story_fbid=10153425681458014\&id= 195819678013); «Jakmile slyším o kládě, vzpomenu si na písničku Beatles Hard day’s night, kde se zpívá: To byla teda dneska těžká makačka a já bych měl spát jako kláda, ale když přijdu domů a jsi tam ty, jsem absolutně v pohodě» (virtually.cz/journal/?q=node/1717) и др. 
чеш. spát (usnout) jako trám ['брус, балка'], peň ['ствол'], poleno ['полено'], špalek ['колода, чурбан'], dřiví ['дрова'], dřvevený [“деревянный'] (ZAORÁLEK 2009: 478, 723; SČFI 449, ČRFS 486) и даже dřvák ['деревянный башмак’].

С одной стороны, этот способ сравнения можно объяснить наличием сем 'тяжелый', 'неподвижный' - если иметь в виду слова колода, балка, брус, ствол, кусок дерева. Это подтверждается использованием аналогичных ассоциативных представлений для передачи в УС иных значений: 1. 'неподвижно' - рус. лежать как бревно (колода) (БСРНС 65); укр. лежить як колода (ССНП 73); чеш. sedi /stojí/leží jako kláda (С̌NK); sedí jako pařez 'сидит как пень' (SČFI 447); 2. 'толстый, неповоротливый, малоподвижный' - рус. толстый, как бревно (колода, полено) (БСРНС 65); tlustý jako špalek ['чурбан'] (ZAORÁLEK 2009: 478); 3. 'тяжелый' - пол. cieźki jak kłoda 'тяжелый как колода' (NKPP 1:325); 4. 'пьяный до бесчувствия' - вероятно, подразумевается 'до неподвижности'; ср. рус. пьяный что колчужка ['обрубок дерева'] (БСРНС 279); пол. pijany jak kłoda (NKPP 2: 926). Ассоциацией с тяжелым, неподъемным, неподвижным или непробиваемым (как в материально-физическом, так и в ментальном, моральном, духовном смыслах) предметом можно объяснить и наблюдаемое говорящими сходство в следующих выражениях: смирный как бревно*; молчит, как бревно*; бесчувственный как бревно*; безмозгльий, как бревно* и проч. ${ }^{6}$

В меньшей степени это кажется убедительным в отношении таких предметов, как полено, дрова, плашка, однако здесь вступает, как нам представляется, в действие иной закон, под который подпадает использование в качестве образа сравнения ряд предметов близкой - «деревянной» - семантики. ${ }^{7}$

В сравнениях весьма активно и указание на иные эталоны, входящие в лексико-семантическую группу «наименование материала»-камень, глину, солому и т. д. Но если основанием для возникновения ассоциации с камнем можно считать его прочность, твердость, вес и неподвижность: pус. cnamb как камень (БСРНС 243); бел. спацьь бы / як камень (СБНП 188); пол. spać jak kamień; śpi jak glina - 'крепко, неподвижно' (NKPP 3: 278); укр. спати як камінь, ${ }^{8}$ то для глины - это скорее вязкость, для соломы - бесформенность, аморфность.

Особую группу составляют и УС, в которых использованы в качестве средства сравнения названия предметов, изготовленных из металла, обычно

\footnotetext{
${ }^{6}$ Примеры со знаком * взяты из Национального корпуса русского языка (НКРЯ).

${ }^{7}$ В. М. Мокиенко отмечает способность слов, объединенных семантикой 'деревянный', служить для передачи значения 'глупый', 'тупой', хотя это не исключает и иных аналогий ср., например, древние ассоциации дерева со здоровьем (ср. этимологическую связь *derev-/ *[z]dorov-) (БМС 2005: 520). В русле подобного восприятия находится и данная Н. В. Гоголем в «Мертвых душах» характеристика героини - дубинноголовая Коробочка, и использованный в стихах нашего современника В. Высоцкого обобщенный образ дерева как эталона глупости: «А если туп, как дерево, родишься баобабом» («Песня о переселении душ»).

${ }^{8}$ В диалектных материалах можно найти и иные «каменные эталоны»: пск. спать как бутик [от бут - 'камень для фундамента'] (БСРНС 75); волог. спать как кремень 'об очень крепко спящем человеке' (БСРНС 308).
} 
воспринимаемого как тяжелый и прочный материал. В русском языке это оборот cnamb как mоnop (БСРНС 685) (те же ассоциации актуализируются и в УС плавать как топор). В южнославянских языках отмечен в качестве образа сравнения артефакт топ 'пушка, орудие', который выступает эталоном и при характеристике сна: болг. заспя (сnя) като mon (FINK 2006: 321); макед. заспие (спие) како топ (FINK 2006: 321); слвн. zaspati (spati) kot top (FINK 2006: 321); хорв. zaspati (spavati) kao top (FINK 2006: 321); серб. cnaвa као mon - 'крепко, глубоко' (МАTEŠIĆ 1982: 214-215), и для характеристики физических качеств - например, глухоты: глув као mon. ${ }^{9}$

Отдельно следует остановиться на сравнительных оборотах, имеющих специфическую и не вполне прозрачную мотивировку: spát jako doch (došek) ['как пучок соломы для кровли'] - 'крепко, неподвижно' (ZAORÁLEK 2009: 475); ср. пол. leży jak kloc ['солома после обмолота'] (SP 73); чеш. spát jako snop ['сноп'] - 'крепко' (ZAORÁLEK 2009: 584); бел. спаųь як сноп гніль (СБНП 188). Можно предположить, что на выбор эталона сравнения с «соломенной» семантикой повлияло ассоциативное сходство расслабленной позы спящего человека и бесформенности, отсутствия четких границ названных предметов. Однако другие УС с использованием в качестве эталона сноп говорят скорее в пользу актуальности сем 'тяжелый', 'неподвижный': чеш. těžký jako snop 'тяжелый'; leželi jako snopové 'неподвижно'; napitý jako snop 'пьяный’ (ZAORÁLEK 2009: 584); рус. валиться / повалиться (падать, покатиться, ynacmь) как сноп (снопом) 'о внезапно, резко и тяжело упавшем человеке' (БСРНС 627).

Образный стержень, использованный в чешских и болгарских УС, также не располагает к однозначной трактовке, ср.: чеш. spát jako moučný pytel (ZAORÁleK 2009: 570); spát jako měch ['мешок'] (pytel/měch 'матерчатое вместилище для чего-л. сыпучего’) - ‘крепко, неподвижно’ (ZAORÁLEK 2009: 530); болг. спя (заспивам/заспя) като тулум [1. 'мех, бурдюк'; 2. 'торба'; 3. разг. ‘брюхо’] - ‘глубоко, непробудно' (ФРБЕ 1: 513). Сопоставление ряда сравнений чешского языка, объединенных этим эталоном, показывает, что данный образ в известной степени десемантизирован. В значении большинства УС компоненты pytel и měch участвуют в формировании семантики 'интенсивность проявления признака сравнения': ‘очень глупый', 'очень темно', 'очень воняет', 'очень густой (туман)', 'очень грязный', 'очень уставший', 'очень пьяный', ‘абсолютно неспособный к каким-л. действиям' и др. Омонимичность слов те̌ch ('мешок'; 'мох'; 'кузнечные мехи') затрудняет прояснение внутренней формы оборота spát jako měch. С одной стороны, резонно допустить, что сравнение с инструментом кузнеца осуществляется на основе зрительной ассоциации - сходства вздымающейся во время крепкого

${ }^{9} \mathrm{Cp}$. аналогичную способность, развиваемую эталонами сравнения с семантикой 'дерево и его части' - бревно, пень и др. Интересно, что образ пушки в русской УС использован для характеристики крепкого сна совсем по-иному: в обороте хоть из пушки пали отсутствие реакции на громкий звук воспринимается как результат крепкого сна, когда ничто не способно разбудить. 
здорового сна груди человека и раздувания мехов, нагнетающих воздух (ср. dýchá jako měch 'тяжело'). Однако пол. устар. chrapie jak kowalskie miechy (cp. также: jak miech kowalski sapie [dyszy i in.]) (NPPP 3: 447) и чеш. funí jako kovářský měch (ZAORÁLEK 2009: 530) свидетельствуют все же в пользу кузнечных мехов и позволяют говорить о связи семантики УС со звуком: 'громко храпеть, тяжело и громко дышать, сопеть'. Этот образный стержень используется и в русских УС, характеризующих дыхание: nыxmemь (conemb) как в кузне мех 'о тяжело вздыхающем, тяжело дышащем человеке'; nblxmemb (сопеть) как ковальский (кузнецкий) мех 'о недовольно пыхтящем человеке'; раздыпаться словно мех 'о тяжело и шумно дышащем'; легкие у кого как кузнечные мехи 'здоровые, мощные, объемные' (БСРНС 392).

Представление о том, что оздоровительные водные процедуры - купание и баня - способствуют хорошему, крепкому сну, отразилось в выражениях: болг. спя като къпан (БРФ 301); укр. спати /заснути мов [як, наче] після купелю (ССНП 79); пол. śpi jak ро łaźni (NKPP 3: 278); серб. спавао сам као окупан. С другой стороны, этот оборот может входить и в группу выражений, реализующих обобщенную образную схему (структурно-семантическую модель) «спать как после некоторых событий», которая может быть конкретизирована - как, например, в чеш. spát jako po výprasku 'спать как после порки' (ZAORÁLEK 2009: 616), допускающей такое понимание, как 'без сил, без чувств, крепко'. Сравнения, детализирующие эту обобщенную схему, будут рассмотрены нами ниже.

Модель «крепкий сон как следствие некоторых событий» реализуется в УС многих языков через образы, связанные с представлением об усыпляющем воздействии мака и маковой воды (отвара) как способных вызвать продолжительный, беспробудный, крепкий сон: рус. сnать как маковой воды (маковок) напившись (БСРHC 105); spát jako by se makovic najedl (ZAORÁLEK 2009: 723); spát jako by mu makovic navařil (ZAORÁLEK 2009: 723); пол. jakby makiem zasypany śpi (WYSOCZAŃSKI 2005: 116); укр. спать як після маку; спать як після маківки (ССНП 87); бел. спацьь як маку наеўшыся (як пасля маку) (СБНП 252); спаць ек послі макоўкі (СБНП 253).

В чешском языке представление о здоровом, крепком сне реализуется и через сравнение спящего с дубом и буком, ср.: spát jako dub; spát jako buk (ZAORÁleK 2009: 46) - т. е. деревьями, выступающими в качестве символов здоровья, богатырской силы, роста, крепости: рус. спать богатырским сном. Это получило не только лексикографическое отражение, но активно используется и в современной речи: silný jako dub, zdravý jako dub, pevný jako dub, urostlý jako dub, rozložitej jako dub, statný jako dub; církev s kořeny jako dub ${ }^{10}$ 'церковь с корнями как у дуба', т. е. 'прочными'. В традиционной культуре славян дуб - самое почитаемое дерево, связанное с богом-громовержцем и символизирующее силу, крепость, мужское начало. Дуб - также место совершения религиозных обрядов, объект и локус жертвоприношений (СД 2: 141).

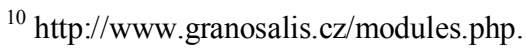


Мотивировка чешского оборота spát [chrápat] jako o půlnoci (SČFI 295) легко объяснима - человека, безмятежно спящего глубокой ночью, вряд ли одолевают тревоги и заботы, его сон спокоен и крепок, тем более что самый крепкий сон, объективно, приходится на первую его фазу. Часто к этой УС прибегают, характеризуя спящего в неположенное время (днем) или пренебрегающего при этом своими обязанностями, что вносит в значение дополнительный оттенок 'в неположенное время', сопровождаемый элементом осуждения, удивления.

К этой же группе со значением «крепко спать» относятся русские диалектные единицы спать как волка съевщи; спать как собаку съевши (БСРНС 637) и спать лоском (лоск лоском) (БСРНС 355). В первых УС возможны такие варианты объяснения внутренней формы: «волка (собаку) съел $\rightarrow$ сытый желудок $\rightarrow$ спокойный сон» или же: «волка (собаку) съел $\rightarrow$ переполненный желудок $\rightarrow$ с трудом двигаться $\rightarrow$ спать крепко, неподвижно». В зависимости от способа прояснения внутренней формы этих оборотов возможно вычленение дополнительных семантических оттенков. В современной русской речи встречается достаточно прозрачное по своей мотивировке выражение спать как удав, перевариваюший кролика (Козлова 2001: 41) с общим значением 'крепко'. УС спать лоском означает не только 'крепко, беспробудно', но и 'лежа вповалку' (БСРНС 355), что объясняется диалектным значением слова лоском (лозгом) 'наповал, грудой' (БМС 2005: 399-400).

УС спать как пожарник 'о длительном крепком и безмятежном сне' (ср. совр. на пожарника сдавать 'долго спать') и зафиксированное на Кубани выражение спать как пожарная лошадь 'о чьем-л. длительном, крепком и безмятежном сне' (БСРНС 516) отражают насмешку над пожарными, намекая на возможность спокойно спать в рабочее время - при отсутствии пожаров, которые, к счастью, случаются не часто.

Еще одна профессия нашла отражение в русской диалектной единице спать как сапожник (БСРНС 592). Сравнительный компонент здесь десемантизирован и выступает в качестве интенсификатора негативных признаков (ср. напиться как сапожник, ругаться как сапожник, работать как сапожник), не имея прямой связи с указанной профессией.

Следует отметить, что сравнительно-сопоставительные исследования во многом зависят от равноценности источников материала. В настоящее время в области УС самый обширный лексикографически обработанный материал, значительная доля которого приходится на обороты диалектного происхождения, содержится в «Большом словаре русских народных сравнений» В. М. Мокиенко и Т. Г. Никитиной (БСРНС). Поэтому в нашей статье диалектный материал представлен в большей степени русскими оборотами, хотя встречаются среди приведенных и диалектные УС польского и чешского языков.

По нашим наблюдениям, диалектные единицы нередко укладываются в рамки существующих и описанных выше структурно-семантических моделей, сохраняя или дополняя образы литературных УС, например: 1) «спать как деревянный предмет»: орл. спать как колчушка [1. 'колода, обрубок'; 
2. 'крепкое, прочное дерево'] (БСРНС 279); брян. неодобр. как льлко [“волокнистое неокрепшее подкорье, молодой луб (от липы), употребляемое для изготовления мочала, лаптей, рогожи и др.'] 'о беспробудно спящем человеке' (БСРНС 363); 2) «спать как мертвый»: пск. спать как пропасный ['пропащий, мертвый'] (БСРНС 541); кар. спать как умрущее 'об очень крепко спящем человеке' (БСРНС 707).

Но иногда в диалектных единицах обнаруживаются случаи такой конкретизации общей структурно-семантической модели и такие образы, которые не встречаются в современном литературном языке. Так, структурно-семантическая модель УС устар. прост. спать точно коноплю продал 'об очень крепко спящем человеке' (БСРНС 283) поддерживается в разных русских говорах значительной группой оборотов со значением 'спать крепко, как после удачной торговой сделки', демонстрирующих широкий спектр образной детализации: брян. спать як лутье продавши; кар. (белом.), пск., смол. спать как пеньку продал (продавши); пск. спать как лен продавии; спать как быков (корову) продал (ИвАшко 1981: 80); волгогр. спать как пшенииу продавши; спит как коней продавши. Подобные единицы встречаются и в белорусском языке, где «реестр» проданного товара особенно широк: як канаплі прадайши; спаць як пяньку прадаўшы; спацьь як авёс (пшэнічу) прадаўшьл (продаў); спаць як валоў (вала, козы); спаџь як лапщі прадаўшы; спацьь як муку прадаўuы; спац̧ь як венікі прадаўшы; спаџь як гарох прадаўшы (СБНП 329).

Мотивировка значения представляется достаточно прозрачной: спать, выпив за удачно совершенную торговую сделку так называемый мaгapыч подношение в виде выпивки. Крепкий сон мотивируется состоянием сильного опьянения: мертвецки, как коней продавши 'о пьяном' (БСРНС 284), что дает нам основание включить эти УС в группу «спать крепко, неподвижно, беспробудно». Но продажу и крепкий сон, можно, на наш взгляд, объяснить и состоянием легкости, чувством успешно завершенного дела, освобождением от бремени, позволяющем спать беззаботно и крепко, что доказывается и значением, приведенным белорусскими лексикографами: cnaub як мyку прадаўшы 'пра моцны бесклапотны сон' (ФСБМ 2: 47); спащь як пшэніиу nродай 'пра моцны, спакойны, бесклапотны сон кагосьці' (СБНП 339).

Несколько сложнее обстоит дело с УС (сnать) как землю продавши (как земля продана) (БСРНС 219), которое (кроме псковского и пермского говоров) встречается в латышском и литовском языках, но с другим значением. Л. А. Ивашко предполагает, что это балтизм, поскольку выражение зафиксировано на пограничье Псковщины и Латвии, ср. лит. kaip žeme pardavęs 'грустный, опечаленный'; латыш. kā tēvu zemi butu pārdevis 'полный отчаяния’, латыш. курзем. kā zemi pārdevis ‘печально, уныло’ (ИвАшко 1981: 80). Этот оборот со значением 'быть в отчаянии' присутствует и в белорусском языке: хадзіųь як зямли прадаўшы 'пра прыгнечаны, разгублены, нярадасны стан чалавека' (СБНП 173). Согласно мнению Л. А. Ивашко, крестьянин приходит в отчаяние, продав землю - свое единственное достояние. Псковский оборот воспринимается исследователем как следствие контаминации балтий- 
ских выражений с псковскими и другими диалектными единицами типа как лен продавии (ИвАшко 1981: 80).

Таким образом, ФЕ, совпадающая по структурной модели - и отчасти лексическому оформлению - с другими единицами, способна изменить свое значение и пополнить представленный в русских говорах синонимический ряд. А широкий перечень продаваемых товаров, представленный в УС, лишь облегчает вхождение очередной версии оборота в структурно-семантическую модель, окрашивая ее общей семантикой. Примыкает к названным единицам, связанным представлением о проданном товаре, о больших ярмарках в прошлом, белорусское УС спіиь як пасля кірмашу (Янкоўскі 1973: 429), где кірмаш - 'большой святочный базар'.

На периферии рассматриваемой группы осталась чешская единица spí jako tuhej (ZAORÁLEK 2009: 723), где компонент tuhej 'жесткий, твердый, упорный, ожесточенный' выступает в роли десемантизированного интенсификатора, ср. употребление его с глаголом обобщенного значения dělat jako tuhej или в УC usnul jako tuhý; byl jako tuhý (ZAORÁLEK 2009: 602).

Такую же роль, как нам кажется, играет в составе УС компонент «слон», который мы обнаружили только в хорватском УC spavati kao slon (TANOvić 2000: 153) и русском спать как слон (КК). Основанием для подобного сравнения служат размеры слона как эталона крупного предмета (животного), который, соответственно, способен и на более сильное, по сравнению с человеком, проявление определенных качеств, свойств, чувств и проч. Как пишет Д. В. Сичинава: «Выражение устал, как слон употреблял еще СергеевЦенский в переписке с Горьким сто лет назад. А еще можно пить, как слон; курить, как слон; спать, как слон; есть, как слон... Все проявления свойств и эмоций слона - конечно, не всерьез - как бы многократно увеличены по сравнению со свойствами и эмоциями людей, которые гораздо меньше слона. Поэтому как слон может означать просто 'очень сильно' применительно к чему угодно, в том числе и к удовольствию» (http://thequestion.ru/questions/ 1866/pochemu-govoryat-ya-dovolen-kak-slon). ${ }^{11}$

Таким образом, устойчивые сравнения, характеризующие крепкий сон, образуют в славянских языках весьма значительную группу. Использование разных образов порождает семантическую дифференцированность, позволяющую выделить подгруппы с добавочными оттенками значения: 1. 'спать крепко, безмятежно, спокойно' с образом спящего ребенка - основным эталоном безмятежного сна, представленным во всех славянских языках; 2. незначительная по количеству подгруппа 'спать крепко, безмятежно, в удобном положении' - в качестве эталона чаще всего выступают представители высших социальных слоев; 3. УС с семантикой 'спать крепко, много, долго' и основным интернациональным образом («животное, впадающее в зимнюю

${ }^{11}$ Использование наименований крупных животных - эталонов большого (лошадь, бегемот, буйвол, кабан, корова и др.), наблюдается и в современных выражениях, отмечающих нечто значительное не только по размеру, но и, к примеру, по стоимости: «Почему оперативная память стоит таких конских денег?» ('больших, как конь'). 
спячку»), обобщившим примечательное разнообразие грызунов - оценки такого сна могут варьироваться от позитивной до негативной; 4. УС 'спать крепко, неподвижно', реализующие распространенную модель «спать как неживой человек», «спать как тяжелый предмет». Судя по количеству и разнообразию этих УС, наиболее важным признаком крепкого сна является неподвижность - обороты, в которых актуализируется сема '(спать) неподвижно', составляют наиболее представительную в славянских языках подгруппу. В качестве эталонов крепкого сна чаще других используется широкий ассортимент деревянных предметов хозяйственного назначения, оцениваемых как тяжелые и потому неподвижные, и наименования мертвого (различными способами убитого) человека. Активность образа неживого, подтверждаемая и диалектным материалом, вызвана, вероятно, тесной мифологической связью сна и смерти - в языковой картине мира славян семантическое поле смерти занимает одно из важнейших мест (см. СмоляковA 1984, BIERICH 1998).

В ряде случаев можно говорить о наличии УС, реализующих одну структурно-семантическую, образную модель, у большинства славян или во всех языках. При этом речь не идет о заимствовании - совпадения являются результатом наблюдений за окружающим миром и идентичных ассоциаций, возникающих у носителей разных языков: спит как ребенок/как колода/ как мертвый. В рамках общей модели отмечается в отдельных языках варьирование образа - как в УС болгарского языка, фиксирующих различные способы «ухода из жизни» (като заклан/удавник/разпран), в белорусских УС с их богатым ассортиментом проданных «товаров» (як канаплі пяньку / пшэніщу/вала/лапці/венікі прадаўшы), или его детализация - как в польском, где крепкий сон ребенка объясняется купанием (śpi jak niemowlę po kapieli).

Нельзя, однако, исключить и взаимовлияние территориально соседствующих языков - например, русского и белорусского в случае с УС, построенными по модели «спать как после торговой сделки», или южнославянских УС с образом пушки.

Материал содержит и обороты с оригинальными эталонами, используемыми 1) только в одном из рассматриваемых языков, например, рус. как пожарник; как сапожник; как волка съевии; чеш. spi jako do foroty; jako dudek; jako Šipková Růženka и др.; пол. śpi jak glina; śpi jak ser w pierogu; слвц. spat' ako v oleji (ako v mlieku); бел. сnац̧ь як за сияну заваліўся; болг. спя (заспивам/заспя) като къпан и др.; или 2) в группе языков: таковы УС чешского и словацкого языков с мотивом падания в воду, перекликающимся с мотивом смерти, хорватское и русское - по модели «спать как большое животное», представленные в нескольких языках УС «спать как после оздоровительных процедур (купание, баня)», «спать как нечто бесформенное» (мучной мешок, пучок соломы)», «спать как после снотворного (мака)» и т. д.

Нельзя не отметить той частоты, с которой в УС анализируемой семантики отмечаются компоненты (эталоны), во многом десемантизированные, чье использование оправдано в первую очередь функцией интенсификации (рус. спать как сапожник; пол. spać jak najęty; чеш. spát jako tuhý). 
Являя огромное разнообразие способов выражения семантики «спать крепко», устойчивые сравнения не всегда позволяют дать однозначную трактовку связи образа и значения, однако большая часть материала вполне убедительно распределяется по основным структурно-семантическим моделям, представленным в славянских языках, что подтверждается и диалектным материалом, который в целом укладывается в «прокрустово ложе» показанных нами образных компаративных структур.

\section{Электронные ресурсы}

НКРЯ = Национальный корпус русского языка. http://www.ruscorpora.ru.

ČNK = Český národní korpus. http://www.korpus.cz.

SCS = Slovnik cizich slov. http://slovnik-cizich-slov.abz.cz.

\section{Литература}

АлЕшин 2012 = АлЕшин А. С. Устойчивые сравнения шведского языка: лингвокультурологический аспект. Санкт-Петербург: «Нестор-История», 2012.

БМС 2005 = БИРИХ А. К., МокИЕНко В. М., СТЕПАНОВА Л. И. Русская фразеологиия. Историко-этимологический словарь. Москва: «Астрель», «АСТ», «Люкс», 2005.

Бойко 2009 = Бойко Л. Г. Культурно маркированное содержание устойчивых сравнений русского языка. АКД. Волгоград, 2009.

БРФ = КОШЕЛЕВ А. К., ЛЕОНИДОВА М. А. (ред.) Болгарско-русский фразеологический словарь. Българско-руски фразеологичен речник. Москва: «Русский язык», София: «Наука и изкуство», 1974.

БСРНС = МокиЕнко В. М., НикитинА Т. Г. Большой словарь русских народных сравнений. Москва: «ОЛМА Медиа Групп», 2008.

ВОРОБЬЕВА 2002 = ВОРОБЬЕВА Л. Б. Русские устойчивые сравнения в сопоставлении с литовскими: специфика образности. Диссертация кандидата филологических наук. Псков, 2002.

Даль = ДАль В. И. Толковый словарь живого великорусского языка. Т. 1-4. Москва: «Прогресс», «Универс», 1994.

Даль 1974 = Даль В. И. Пословищы русского народа. Т. 2. Москва: «Художественная литература», 1974.

ЖуМАНБЕКОВА 2013 = ЖуМАНБЕКОВА Н. 3. Образная составляющая устойчивых сравнений в немецком и казахском языках. В кн.: Сборник научных трудов по итогам III Международной научной конференции «Когнитивные факторы взаимодействия фразеологии со смежными дисииплинами». Белгород: «БелГУ», 2013.

ИвАшКО 1981 = ИвАшкО Л. А. Очерки русской диалектной фразеологии. Ленинград: «Издательство Ленинградского университета», 1981.

КК = Картотека проекта «Ключевые концепты русских народных сравнений (опьт идеографического словаря)» (№ 14-04-00090/14; шифр ИАС 31.16.571.2014).

КовшовА 2013 = КовшовА М. Л. Лингвокультурологический метод во фразеологии. Коды культуры. Москва: «Либроком», 2013.

КозЛОВА 2001 = КозЛовА Т. В. Идеографический словарь русских фразеологизмов с названиями животных. Москва: «Дело и сервис», 2001. 
КуЗНЕЦОВА $2011=$ КУзНЕЦОВА И. В. Славянские устойчивые сравнения о магической практике. Вестник Орловского государственного университета 2011/1: 187-190.

КузНЕцОВА 2012 = КУзНЕцОВА И. В. Славянские устойчивые сравнения с компонентом - названием профессии. В кн.: Die Phraseologie in Raum und Zeit. Greifswald: «Ernst Moritz Arndt Universität», Санкт-Петербург: «Филологический факультет СПбГУ», 2012. 110-113.

КЮвЛИЕВА-МИШАЙКОВА 1986 = КЮвЛИЕВА-МишАЙКОВА В. Устойчивите сравнения в българския език. София: «Издателство на българската академия на науките», 1986.

ЛЕБЕДЕВА 1999 = ЛЕБЕДЕВА Л. А. Устойчивые сравнения русского языка во фразеологии и во фразеографии. Краснодар: «Кубанский государственный университет», 1999.

ЛЕВЧЕНкО 2012 = ЛЕВЧЕНко О. Украӥнсько-білорусько-болгарсько-польский словник порівнянь. Львів: «Видавництво Львівської політехніки», 2012.

Мизин 2011 = Мгзн К. І. Людина в дзеркалі компаративної фразеології. Кременчук: «ПП О. В. Щербатих», 2011.

Мокиенко 2003 = МокиЕнко В. М. Словарь сравнений русского языка. Санкт-Петербург: «Норинт», 2003.

МРБС = САНьКО З. Малы руска-беларускі слоўнік прыказак, прымавак $і$ фразем. Мінск: «Навука і тэхніка», 1991.

НикОЛАЕВА 1989 = НикОЛАЕВА Е. К. Идеографическое описание компаративных фразеологических единии польского языка. АКД. Ленинград, 1989.

НикОЛАЕВА 2015 = НикОЛАЕВА Е. К. О культурной семантике устойчивых сравнений. В кн.: Русский язык и литература в пространстве мировой культуры. Материаль ХІІІ Конгресса МАПРЯЛ, г. Гранада, Испания. 13-20 сентября 2015 г. Т. 6. Санкт-Петербург: «МАПРЯЛ», 2015. 399-405.

ОГОЛЬЦЕВ 2001 = ОГОЛЬЦЕВ В. М. СЛоварь устойчивых сравнений русского языка (синонимо-антонимический). Москва: «Астрель», «АСТ», 2001.

Полищук 2014 = Полищук А. ЧЕЛОВЕК УМНЫЙ в славянской компаративной фразеологии (на материале Украинско-русско-белорусско-болгарско-польского словаря сравнений Е. П. Левченко). В кн.: Stowo. Tekst. Czas XII. Frazeologia w idiolekcie i systemach językow słowiańskich. W 200. rocznice urodzin Tarasa Szewczenki. Szczecin: Uniwersytet Szczeciński, Greifswald: Ernst Moritz Arndt Universität, 2014.

РСХКЈ = Речник српскохрватскога книжевног језика. Нови Сад: Матица Српска, Загреб: Матица Хрватска, 1967-1976.

СБНП = Слоўнік беларускіх народных параўнанняў. Уклад. Т. В. Валодзіна, Л. М. Салавей; навук. рэд. В. М. Макіенка. Мінск: «Беларуская навука», 2011.

СД = Толстой Н. И. (ред.) Славянские древности. Этнолингвистический словарь. Т. 2. Москва: «Международные отношения», 1995.

СмоляковА 1984 = СмоляковА Н. А. Семантические поля в болгарской фразеологии. АКД. Ленинград, 1984.

ССНП = Юрченко О. С., ІвченкО А. О. Словник стійких народних порівнань. Харків: «Основа», 1993.

ТЕЛИЯ 1996 = Телия В. Н. Русская фразеология. Семантический, прагматический и лингвокультурологический аспекты. Москва: «Языки русской культуры», 1996.

Флоренция 2008 = Флорениия. Искусство и история. Firenze: Bonechi, 2008.

ФРБЕ = НИЧЕВА К., СПАСОВА-МИХАЙЛОВА С., ЧОЛАКОВА Кр. Фразеологичен речник на български език. Т. 1-2. София, 1974-1975. 
ФСБМ = ЛЕПЕШАЎ І. Я. Фразеалагічны слоўнік беларускай мовы. Т. 1-2. Мінск, 1993. ШиРоковА 1988 = ШиРоковА А. В. Сопоставительная типология разноструктурных языков. Москва, 1988.

Янкоўскі 1973 = Янкоўскі Ф. М. Беларускія народныя параўнанні. Кароткі слоўнік. Мінск: «Вышэйшая школа», 1973.

BC 2004 = BoŠNJAK T., CĂPĂTONĂ C. Hrvatski i rumunjski frazemi za izricanje osobina. Riječ. Časopis za slavensku filologiju 2004/2: 22-27.

BIERICH 1998 = BIERICH A. The semantic field "Death" in Czech, Russian, Croatian and Serbian phraseology. In: Ďurčo P. (red.) Europhras '97. Phraseology and Paremiology. Liptovský Ján, 2-5.9.1997. Bratislava: Akadémia PZ, 1998. 17-23.

ČRFS = MOKIENKO V., WURM A. Česko-ruský frazeologický slovník. Olomouc: Univerzita Palackého v Olomouci, 2002.

FINK 2006 = FINK-ARSOVSKI Ž. i sur. Hrvatsko-slavenski rječnik poredbenih frazema. Zagreb: Knjigra, 2006.

FINK 2007 = FINK-ARSOvSKi Ž. Hrvatski poredbeni frazemi sa značenjem 'spavati' i 'zaspati'. In: Frazeologia a językowe obrazy świata przełomu wieków. Opole: Uniwersytet Opolski, 2007. 281-287.

FinK 2010 = FinK-ARSOVSKi Ž. 'Kuga (чума)' в сравнительных фразеологизмах хорватского, русского и некоторых других языков. В кн.: Фразеология, познание $u$ культура. Сборник докладов 2-й международной научной конферениии. Белгород, 7-9 сентября 2010 г. Т. 1. Белгород: «БелГУ», 2010. 270-274.

FINK 2012 = FINK-ARSOVSKI Ž. Hrvatski frazemi s komponentama spavati, zaspati, san i njihovi ruski ekvivalenti. In: Stručak riječima ispunjen. Zbornik radova posvećen Antici Menac o njezinu 90. rođendanu. Zagreb: Filozofski fakultet Sveučilišta u Zagrebu, 2012. 47-62.

MATEŠIĆ 1982 = MATEŠIĆ J. Frazeološki rječnik hrvatskog ili srpskog jezika. Zagreb: Školska knjiga, 1982.

MenaC-Minalić 2003-2004 = MenaC-Minalić M. Hrvatski dijalektni frazemi s antroponimom kao sastavnicom. Folia Onomastica Croatica 12-13 (2003-2004): 361-385.

Mokienko-Walter-Valodzina 2004 = Mokienko V., Walter H. Valodzina T. Slawisch-germanische Projektionen pomoranischer Redewendungen (animalistische Phraseologismen mit der Komponente „Hund“). In: Die Geschichte des pommerschen Dorfes II. Internationale wissenschaftliche Konferenz. Degow-Stättin, 2004. 191-210.

NKPP = KRZYŻANOWSKI J. (red.) Nowa księga przystów $i$ wyrażeń przysłowiowych polskich. T. 1-4. Warszawa: PIW, 1969-1978.

SČFI = ČERMÁK Fr., HRONEK J., MACHAČ J. (red.) Slovník české frazeologie a idiomatiky. Přirovnání. Praha: Academia, 1983.

SFJP = SKORUPKA S. Słownik frazeologiczny języka polskiego. T. 2. Warszawa: Wiedza Powszechna, 1967.

SMIEŠKOVÁ 1974 = SMIEŠKOVÁ E. Malý frazeologický slovník. Bratislava: Slovenské pedagogické nakladatel'stvo, 1974.

SP = BAŃKO M. Słownik porównań. Warszawa: PWN, 2004.

TANOVIĆ $2000=$ TANOVIĆ I. Definiranje frazeoložkih jedinica i njihove karakteristike. In: Radovi. Kn. 12. Sarajevo: Filozofski fakultet u Sarajevu, 2000. 143-168.

WYSOCZAŃSKI 2005 = WYSOCZAŃSKI W. Językowy obraz świata w porównaniach zlekalizowanych. Wrocław: Wydawnictwo Uniwersytetu Wrocławskiego, 2005.

ZAORÁleK 2009 = ZAORÁLeK J. Lidová rčení. Praha: Levné knihy, 2009. 